\title{
Lịch sử điều chỉnh biên độ dao động giá HOSE
}

\author{
GSW Capital \\ December 31, 2014 \\ https://gswcapital.wordpress.com/2014/12/31/lich-su-dieu-chinh-bien-do-dao- \\ dong-gia-hose/
}




\section{GSWCapital}

\section{Place/Please your Trust Completely.}

\section{Lịch sử điều chỉnh biên độ dao động giá HOSE}




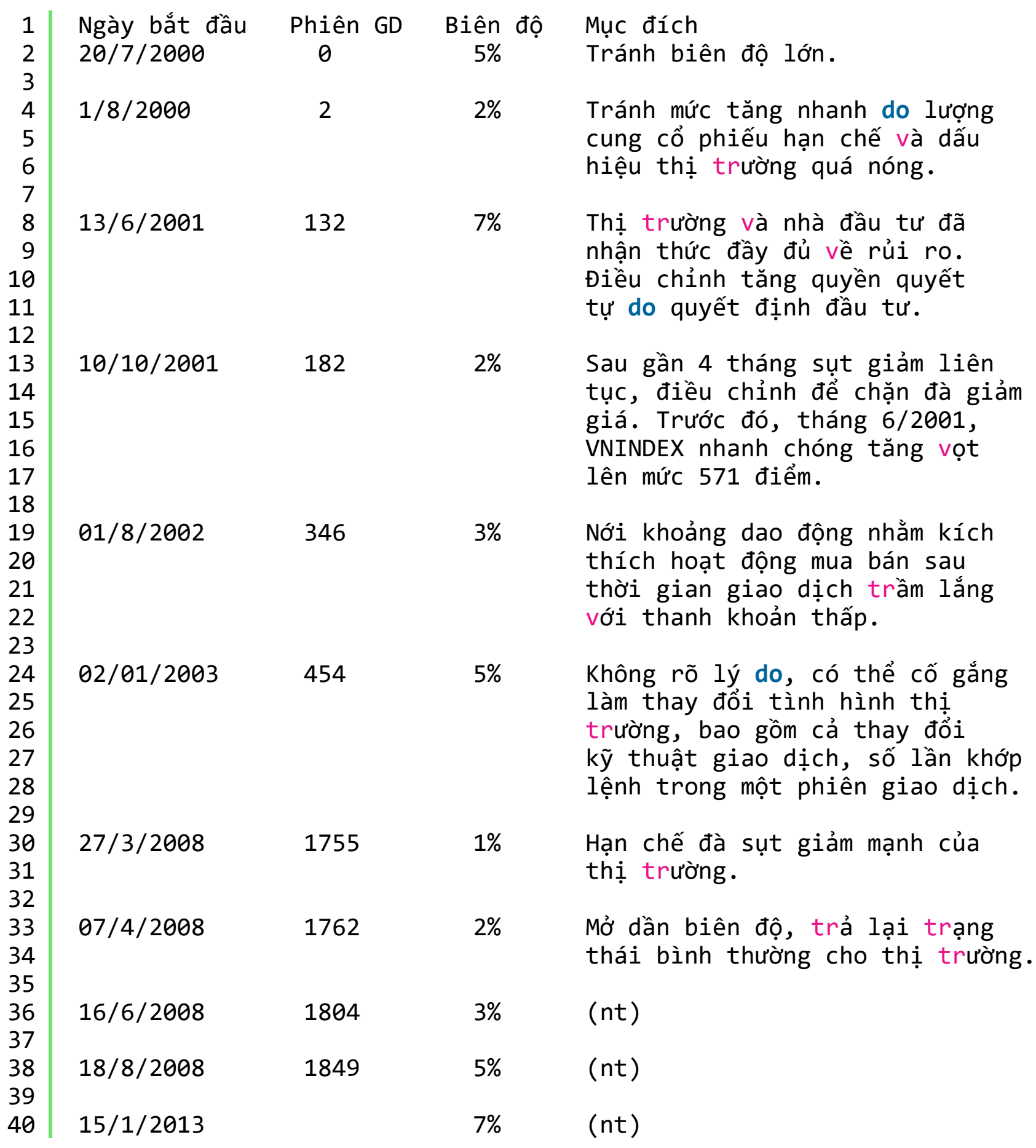

Nguồn tham khảo

[1] Vương Quân Hoàng, Phạm Minh Chính (2010). Kinh tế Việt Nam: Thăng trầm và Đột phá.

[2] http://vietstock.vn/2013/01/thay-doi-bien-do-giao-dich-va-tac-dong-den-ttck-830-254005.htm (http://vietstock.vn/2013/01/thay-doi-bien-do-giao-dich-va-tac-dong-den-ttck-830-254005.htm).

[3] http://cafef.vn/thi-truong-chung-khoan/chinh-thuc-ap-dung-bien-do-moi-tu-151-loi-nhuan-cao-dikem-voi-rui-ro-20130115081157353.chn (http://cafef.vn/thi-truong-chung-khoan/chinh-thuc-ap-dungbien-do-moi-tu-151-loi-nhuan-cao-di-kem-voi-rui-ro-20130115081157353.chn).

Posted in: Kiến thúc Đầu tux, Tin túc-Chính sách | Tagged: biên độ, $\underline{\text { HOSE }}$ 


\section{Tài liệu tham khảo:}

[1] Phạm Minh Chính, Vương Quân Hoàng. (2009). Kinh tế Việt Nam: Thăng trầm và đột phá. Nxb Chính trị quốc gia, Hà Nội.

[2] Hoàng Vũ. (2013). Thay đổi biên độ giao dịch và tác động đến TTCK. Vietstock. http://vietstock.vn/2013/01/thay-doi-bien-do-giao-dich-va-tac-dong-den-ttck-830254005.htm

[3] Phương Mai, Thanh Hương (2013). Chính thức áp dụng biên độ mới từ 15/1: Lợi nhuận cao đi kèm với rủi ro. Trí Thức Trẻ. http://cafef.vn/thi-truong-chung-khoan/chinh-thuc-apdung-bien-do-moi-tu-151-loi-nhuan-cao-di-kem-voi-rui-ro-20130115081157353.chn 